\title{
İlkokul Öğrencilerinin Sorumluluk Algısı ve Öğrenme Deneyimleri: Fenomenolojik Bir Araștırma
}

\author{
Hanifi Şekerci ${ }^{1}$
}

Özet: Son yıllarda değerlerin öğretimi için önemli çalışmalar yapılmaktadır. Daha önceki programlarda (1968, 1998) değerlerin örtük olarak öğretimine dönük etkinlikler varken 2005 yllında düzenlenen öğretim programlarında değerlerin öğretimine dönük kazanımlara, içeriklere ve öğrenme yaşantılarına yer verilmiştir. Söz konusu programlarda öğrencilere kazandırılması amaçlanan değerlerin biri sorumluluktur. Bu değer aynı zamanda sınıf öğretmenleri ve ilkokul öğrenci velilerinin tarafından öğrencilerin kazanmalarını istedikleri değerlerin başında gelmektedir. $\mathrm{Bu}$ araştırmada ilkokul öğrencilerinin sorumluluk algısı ve öğrenme deneyimlerinin belirlenmesi amaçlanmıştır. Böylelikle daha sonra yapılacak sorumluluk değerinin öğretimine çeşitli açılardan önemli yol haritasının sunulabileceği düşünülmüştür. Çalışmada nitel araştırma desenlerinden olgu bilim kullanılmıştır. Araştırmaya Diyarbakır ilinde orta ve alt sosyo ekonomik düzeyde öğrencilerin öğrenim gördüğü bir ilkokuldan 10 öğrenci katılmıştır. Katılımcıların belirlenmesinde tipik durum örneklerimi tekniğinden faydalanılmıştır. Araştırma verileri ise öğrenci resimleri ve yarı yapılandırılmış görüşme formu ile toplanmıştır. Verilerin analizinde ise tematik analiz tekniğinden faydalanılmıştır. Araştırmada elde edilen bulgulara göre ilkokul öğrencileri sorumluluğu iş, görev ve yükümlülük olarak anlamlandırmaktadır. Bunun yanında öğrenciler sorumluluğu aile, okul ve yakın çevreden telkin ve model alma yollarıla öğrenmektedir. Öğrenciler tarafından model olarak alınan kişiler ise çeşitli özelliklerinden ötürü örnek alınmaktadır.

Anahtar Kelimeler: Sorumluluk, İlkokul Öğrencileri, Sorumluluk Eğitimi

Geliş Tarihi: 11.11.2019 - Kabul Tarihi: 25.06.2020 - Yayın Tarihi: 29.06.2020

DOI: $10.29329 /$ mjer.2020.258.16

\section{Primary Schools Student's Perception of Responsibility And Learning Experiences: A Phenomenological Research}

\begin{abstract}
Important studies have been carried out for the teaching of values during recent years. While there were activities for implicit teaching of values in previous $(1968,1998)$ programs, the educational programs that were organized in 2005 included gains for the teaching of values, contents and learning experiences. One of the values that are aimed to be gained to students in these programs is responsibility. This value that the primary school teachers and primary school parents want students to gain is also one of the values. In this research,it was aimed to determine the responsibility perception and learning experiences of students from primary school.
\end{abstract}

\footnotetext{
${ }^{1}$ Hanifi Şekerci, Research Assist Dr., Primary School Teaching, University of Dicle, ORCID: 0000-0002-1280-3228

Correspondence: hnfskrc@gmail.com
} 
Thus, it is thought that an important guiding effect may be presented for teaching the value of responsibility to be made in various aspects. In the study, phenomenology of qualitative research patterns was used. Ten students from a primary school teaching at lower and medium socio-economic level in Diyarbakır participated to the research. The research data were collected via pictures of studens and semi-structured interview form. In the analysis of data,it was made use of thematic analysis technique. According to the findings obtained in the research, primary school students make sense of responsibility as job, duty and obligation. Besides, students learn responsibility via suggestions and models from family, school and immediate vicinity. People taken as models by students are taken as examples thanks to their various characteristics.

Key Words: Responsibility, Responsibility Education, Primary School Students,

\section{GİRIŞ}

Bireyin yaşadığı topluma uyum sağlayabilmesi için bir takım değerlere sahip olması gerekmektedir. Bireye değer kazandırmada en önemli etkiye aile ve okul sahiptir. Aile ortamında ebeveynlerin ve yakın akrabaların, okulda ise öğretmenlerin çocuğun değerleri kazanmasında önemli rolleri bulunmaktadır. Son yıllarda ailenin ve okulun öğrencilerin değerleri kazanmalarındaki rolünü ortaya koyan pek çok çalışmaya rastlanmaktadır. Bunun yanında 2005 yılında yapılandırmacı anlayış ile geliştirilen ve daha sonraki yıllarda revize edilen $(2009,2015,2018)$ öğretim programlarında çeşitli değerlerin öğrencilere kazandırılmasına yönelik hedefler, kazanımlar, yöntemler ve öğrenme içerikleri oluşturulmaya çalışılmıştır. İlkokul kademesinde Hayat bilgisi, Sosyal Bilgiler, Fen Bilimleri ve Türkçe öğretim programları yoluyla çeşitli milli ve evrensel değerlerin öğrencilere kazandırılması hedeflenmektedir. Bu değerlerden biri sorumluluktur.

Sorumluluk karmaşık ve farklı boyutları olan kişilerin hayatını derinden etkileyebilecek bir kavramdır (Moritz, Wahl, Zurowski, Jelinek, Hand \& Fricke, 2007). Bu yüzden sorumlulukla ilgili birçok tanım yapılmıştır. Bu tanımlamalara bakıldığında bazılarının sorumluluğu yerine getirilmesi gereken bir görev olarak ele aldığı görülmektedir. Örneğin Yavuzer’e (2000) göre sorumluluk küçük yaşlardan itibaren çocuğun yaşına, cinsiyetine ve gelişim düzeyine uygun olarak görevlerini yerine getirmesidir. Başaran (1974) ise sorumluluğu üzerine alınan bir işi veya görevi yapma ve gerektiğinde bunlarla ilgili hesap vermeye hazır olma durumu olarak ifade etmiştir. Başaran'ın sorumluluk tanımlamasında görevin yanında sorumluluğun hesap verebilme boyutunun da yer aldığ görülmektedir. Cüceloğlu (1996) da sorumluluğu hesap verebilme boyutuyla tanımlamıştır. Ona göre sorumluluk kişinin sınırları içerisinde gördüğü olaylardan ve şeylerden hesap vermeye hazır olmasıdır. Popkin'in (1987) yaptığı tanımlamada sorumluluk, seçimler yapma ve bu seçimlerin sonuç ve etkilerini kabullenmedir. Civelek (2006) ise sorumluluğu kurallara uyma, başkalarına ve onların sahip olduklarına saygı ve özen gösterme olarak ele almaktadır. Yapılan tanımlamalarda sorumluluğun üstlenilen işleri ve görevleri yerine getirme, seçimler yaparak bunların olası sonuçları ile ilgili hesap verme ve bunları kabullenme olarak ele alındığı söylenebilir. 
Sorumluluğun daha geniş bir perspektifle ele alınarak tanımlanması Lickona tarafindan yapılmıştır. Lickona’ya (1991) göre sorumluluk kişinin kendine ve başkalarına bakım ve özen göstermesi, yükümlülüklerini yerine getirmesi, toplumsal sürece katılması, başkalarının acılarını dindirmeye çalışması ve iyi bir dünya için çaba harcamasıdır. Bu tanımlamada sorumluluğun kişisel ve toplumsal boyutlarına odaklanıldığı görülmektedir. Mowling, Brock ve Hastie (2011) de sorumluluğu kişisel ve sosyal boyutlarıyla ele almıştır. Buna göre kişilerin davranışlarının kişisel sorumluluğunu üstlenmesi, iyi seçimler yapması ve sosyal yaşamda empatiyi benimsemesi kişisel ve sosyal sorumluluğu bir bakıma üstlenmesidir. Sosyal sorumluluk sahibi olmanın ön koşulu ise kişisel sorumluluk sahibi olmaktır. Altun, (1999), Lee ve Kotler (2006) ve Seyyar'a (2003) göre sosyal sorumluluk insanın sosyal hayata dönük yönüdür. Buna göre sorumluluk bireyin sosyal yaşamdaki diğer kişilerin psikolojik ve duygusal ihtiyaçlarını dikkate alması, kendi beklentileri ile toplumun beklentilerini karşılaştırması ve davranışlarında toplumsal çıkarları gözetmesidir. Nelson ve Low $(2004,84)$ ise sorumluluğu kişisel boyutta ele alıp, yaşamda açık amaçlar belirleyip bu amaçlara ulaşmak için tüm sorumlulukları ve görevleri tamamıla kabullenmek olarak ifade etmektedir.

Sorumlulukla ilgili yapılan tanım ve açıklamalarda yola çıkarak sorumluluk sahibi bireylerin üstlendiği görev ve işleri en şekilde yerine getirmeye çalışacağını, vereceği kararlarda toplumun beklentileri ile kendi beklentilerini dikkate alacağını, üstlendiği görev veya işlerden hesap verebileceğini, çevresinde bulunan insanların ihtiyaçlarını gözeteceğini ve onlara saygı duyacağını söyleyebilmek mümkündür. Nitekim Şahan (2011: 12) sorumlu bireyde bulunması gereken özellikleri, yapması gereken görevleri özgür iradesiyle üstlenebilmek, sağlıklı düşünme yeteneğine sahip olmak, ortaya koyacağı davranışın yasal ve ahlaki açıdan uygunluğunu biliyor olmak, davranışları yerine getirip getirmeme durumunda ortaya çıkabilecek olumlu-olumsuz sonuçları, hem yasal açıdan hem de ahlaki yönden üstlenebilmek ve güvenilir bir kimliğe sahip olmak şeklinde açıklamaktadır.

Sorumluluk değeri insanların doğuştan kazandığı bir değer değildir. İnsanların sorumlu davranışlar edinebilmesi için bir takım yaşantılara gereksinim duyulmaktır. Ackerman, Hughs ve Wilder (1997) bu duruma dikkat çekmektedir. Buna göre sorumluluğun öğrencilere kazandırılması için onlarla konuşmak yetersizdir. Bunun yerine onlara sorumluluğu öğrenme firsatlarının sunulması gerekmektedir. Bu bakımdan öğrencilere sorumluluğu eğitim ve gerçek yaşam deneyimleri yoluyla kazandırmak önemlidir (Gunnestad, Mørreaunet, Granseth \& Vikan, 2013; Yeşil, 2013; Yontar \& Yurtal, 2009). Son yıllarda sorumluluğun eğitim yoluyla kazandırılmasına yönelik ihtiyaç artmıştır. Çünkü Yeşil (2014) dünyanın hemen her yerinde yoğun olarak yaşanan sosyal, ekonomik, siyasi, askeri ve ekolojik sorunlarının kaynağının esasen bireylerin sorumluluk bilinciyle hareket etmemelerinden kaynaklandığını belirtmektedir. Bu sorunların çözümü için ise sorumluluk değerinin bireylere kazandırılmasında eğitimin önemli bir işlevinin olabileceği söylenebilmektedir. Bu bağlamda eğitim araştırmaları literatüründe de sorumluluk değeri ile ilgili pek çok çalışmanın yapıldığı da görülmektedir. 
Can (2008) tarafindan yapılan araştırmada, en çok önem verilen değerler sorumluluk ve saygıdır. Öğretmenlerin en çok önem verdiği değerler arasında sorumluluk yer almaktadır (Acun vd., 2013). Sosyal Bilgiler ve sınıf öğretmenlerinin en çok sorumluluk değerini öğrencilerine kazandırmayı amaçlamaktadır (Çelikkaya, Filoğlu \& Öktem, 2013). Veliler okullarda sorumluluk değerini öğrencilere öncelikli olarak kazandırmak istemektedir (Yiğittir, 2010). Bunun yanında Yeşil (2003) tarafindan yapılan çalışmada öğrencilerin büyük bölümünün, sorumluluk boyutunda yer alan davranışları yeterince gösteremedikleri görülmüştür. Baydar'ın (2009) araştırmasında ilköğretim beşinci sınıf öğrencilerinin sorumluluk değerini kazanım düzeyi Kohlberg'in ahlaki gelişim kuramına göre geleneksel düzeydedir. Bu araştırma sonuçlarına göre öğretmen ve öğrenci velilerinin sorumluluk değerine önem verdikleri görülmekteyse de bazı araştırmalardaki (Baydar, 2009; Tay, Durmaz \& Şanal, 2013; Yeşil, 2003) bulgulara göre okulda ve ailede sorumluluk değeri kazandırmaya yönelik uygulamaların yetersiz kaldığı ve birbirini desteklemediği görülmüştür. Bu bağlamda ilkokul öğrencilerinin sorumluluk algılarını ve öğrenme deneyimlerini saptamanın önemli olacağı düşünülmüştür. Çünkü Yeşilyaprak'a (2002) göre ilkokul dönemi öğrencilerin sorumluluk ile ilgili çeşitli yeterlilik ve becerilerini kazanacağı önemli bir dönemdir. Bu dönemdeki öğrencilerin sorumluluğu nasıl algıladıkları ve nasıl öğrendiklerini belirleyebilmenin daha sonraki eğitim süreçlerine de yol gösterebileceği söylenebilmektedir. Bunun yanında ilkokul öğrencilerinin sorumluluk algısını belirlemeye yönelik çalışma (Karakuş, Kartal \& Çağlayan, 2016) yapılmış olsa da bu çalışmada öğrencilerin sorumlu davranışları öğrenme deneyimleri araştırılmamıştır. Bu bakımdan araştırma ilgili literatürde yapılan çalışmalardan önemli noktalarda farklılaşmaktadır. Ayrıca araştırmada elde edilen sonuçların sorumluluk eğitimi konusunda program geliştiren uzmanlara ve öğretmenlere önemli bakış açıları kazandıracağı düşünülmektedir. Bu araştırmanın amacı ilkokul öğrencilerinin sorumluluk algısını ve sorumluluk ile ilgili davranışları öğrenme deneyimlerini araştırmaktadır. Bu bakımdan araştırmada aşağıdaki sorulara yanıt aranmaktadır:

İlkokul öğrencilerinin sorumluğu nasıl anlamlandırmaktadır?

İlkokul öğrencilerinin sorumluluk davranışlarını öğrenme deneyimleri nelerdir?

\section{YÖNTEM}

\section{Araştırmanın Deseni}

$\mathrm{Bu}$ araştırma nitel araştırma desenlerinden olgu bilim kullanılarak gerçekleştirilmiştir. Olgu bilim deseninde bir olguya ilişkin bireylerin deneyimleri ve ona yüklediği anlamlar ortaya çıkarılmaya çalışır (Creswell, 2009; Patton, 2002; Yıldırım \& Şimşek, 2005). Çalışmada ilkokul öğrencilerinin sorumluluk algısı ve öğrenme deneyimleri onların bakışından anlaşılmaya çalışılmıştır. Bu bağlamda ögrencilere öncelikle sorumluluk denilince ne anladıkları ve sorumluluğu nasıl anlamlandırdıklarına dair bir resim çizmeleri istenmiştir. Çocuk resimlerinin olgu bilim deseniyle incelenmesinde çeşitli anlamlara, anlamların oluşturulduğu bağlama ve resmi yapanın dünya görüşüne odaklanılmaktadır 
(Malchiodi, 2005). Araştırmada öğrencilerin sorumluluk algısı öğrencilerin yaptıkları resimlere göre incelenmiştir. Ardından öğrencilerle sorumluluğu nerede, kimlerden ve ne tür uygulamalarla öğrendiklerine ilişkin görüşmeler yapılmıştır.

\section{Çalışma Grubu}

Araştırmada çalışma grubunun seçiminde amaçlı örneklem türlerinden olan tipik durum örneklemesi kullanılmıştır. Glesne’ye (2012) göre bu örneklem türü bir konuya ilişkin ortalama durumları ortaya koymak amacıyla kullanılmaktadır. Çalışmada amaç alt ve orta sosyo-ekonomik düzeydeki öğrencilerin sorumluluk algısını incelemektir. Bu amaçla, araştırma alt ve orta sosyoekonomik düzeydeki öğrencilerin devam ettiği bir ilkokulda gerçekleştirilmiştir. Bu okulda 4. sınıfta öğrenim gören 10 öğrenci araştırmaya katılmıştır.

\section{Veri Toplama Araçları}

Araştırmada veriler öğrenciler tarafından yapılan resimler ve yarı yapılandırılmış görüşme ile toplanmıştır. Çocuk resimleri çocukların iç dünyalarını ve yaşam deneyimlerini anlatan bir ifade biçimidir (Greig, Taylorand \& Mackay, 2007; Leitch, 2008). Yarı-yapılandırılmış görüşmeler ise araştırmacılara konunun ana çerçevesini belirleyip kendi konuları kapsamında soru sorma olanağı vermekte, bunun yanında görüşme sırasında ortaya çıkabilecek yeni durumlara göre sorular eklemeye de olanak tanımaktadır (DiCicco-Bloom \& Crabtree, 2006). Görüşme soruları hazırlanırken ilgili literatür incelenmiştir. Ardından araştırmanın amacına uygun olarak sorular hazırlanmıştır. Daha sonra araştırmanın amacı ve sorularını içeren görüşme formu alan uzmanlarına (üç alan ve dil bilimci) sunulmuştur. Onlardan gelen dönütlere göre gerekli düzenlemeler yapılmış ve görüşme formuna son şekli verilmiştir. Görüşme formunda yer alan sorular öğrencilerin sorumluluğu nasıl algıladığ1, sorumluluk ile ilgili davranışlarının neler olduğu ve bunları nasıl öğrendiği ile ilgilidir.

\section{Verilerin Toplanması ve Analizi}

Araştırma verilerinin toplanması için okul yönetimi ve öğretmenden izin alınmıştır. Ardından görüşmelerin daha sağlıklı yapılabilmesi için okul içinde uygun bir odaya geçilmiştir. İlk aşamada ögrencilere sorumluluk deyince ne anladıklarını ve sorumluluğu nasıl anlamlandırdıklarını anlatan bir resim ve altına bu resim ile ilgili açıklama yapmaları istenmiştir. Bunun için öğrencilere yaklaşı 20 dakika süre verilmiştir. Ardından yarı yapılandırılmış görüşme soruları odak grup görüşme tekniği kullanılarak öğrencilere yöneltilmiştir. Burada her bir öğrenciye sırasıyla sorular sorulmuş öğrenciler tarafından verilen yanıt sona erdiğinde aynı soru bir başka öğrenciye yöneltilmiştir. Her bir soru tüm öğrenciler tarafından yanıtlandıktan sonra söz konusu soruya ilişkin ekstra görüş belirtmek isteyen öğrencilere tekrardan firsat verilmiştir. Öğrencilerle gerçekleştirilen odak grup görüşmesi yaklaşık 30 dakika sürmüştür. Araştırmacı görüşmenin başlangıcında, görüşmenin amacının ve nasıl yürütüleceğini öğrencilere açıklamış ve verilerin güvenilir bir biçimde elde edilebilmesi için ses kayıt cihazı ile kaydetme izni almıştır. 
Çocukların resimsel anlatımlarından ve resimsel anlatımına dayalı yazılı ifadelerden elde edilen veriler doküman incelemesi yoluyla incelenmiştir. Çalışmada çocukların yaptıkları resimler üzerine konuşmaları sağlanmış ve resimlerin analizinde çocuklarla resimlerine ilişkin yaptıkları yazılı açıklamalar temel alınmıştır. Verilerin çözümlenmesi aşamasında, öğrencilerin çizmiş oldukları resimler ve yazılı ifadeleri araştırmacı tarafından analiz edilmiştir.

Yarı yapılandırılmış görüşmelerin analizinde ise tematik analiz tekniğinden yararlanılmıştır. Liamputtong (2009) tematik analizde verilerin kavramsallaştırılması ve temaların ortaya çıkarılmasının amaçlandığını belirtmektedir. Verilerin analizi için öncelikle ses kayıtları hiçbir değişiklik yapılmadan olduğu gibi görüşme formuna aktarılmıştır. Böylelikle katılımcıların söylediği her şey yazılı hale getirilmiş ve tek tek okunarak değerlendirilmiştir. Okunma işleminin ardından veriler kodlanmış ve kodlamalar temalar altında toplanmıştır. Hem resimsel anlatımların hem de yarı yapılandırılmış görüşmelerin analizi için alan uzmanı görüşü alınmıştır. Alan uzmanı nitel araştırma konusunda deneyimi olan ve sınıf eğitimi alanında doktora yapmış bir akademisyendir. Alan uzmanı yapılan kodlamaları ve kodlamaların altında yer aldığı temaları incelemiştir. Değerlendirmeler sonucunda ortak kodlamalar ve temalar belirlenmiştir. Yapılan değerlendirme sonucunda kodlayıcılar arası tutarlılık \% 91 olarak hesaplanmıştır. Miles ve Hubermann'a (1996) göre iki analiz arasında tutarlılığın \%70'in üzerinde olması yeterlidir. Bu bakımdan veri analizinde elde edilen tutarlılık oranının araştırmanın güvenirliği açısından bir sorun teşkil etmediği söylenebilir. Son aşamada ise, öğrencilerin görüşleri belirlenen temalar çerçevesinde sunulmuş ve doğrudan alıntılar yapılarak çalışma desteklenmiştir.

\section{BULGULAR}

Araştırmada verilerin analizi sonucu ortaya çıkan temalar "öğrencilerin sorumluluk algısı, sorumlulukların ilgili oldukları alan, sorumlulukların öğrenildiği yerler ve öğrenilme şeklidir”. Aşağıda bu temalar ve bu temaların bazılarının alt kategorileri Şekil 1'de sunulmuştur. 


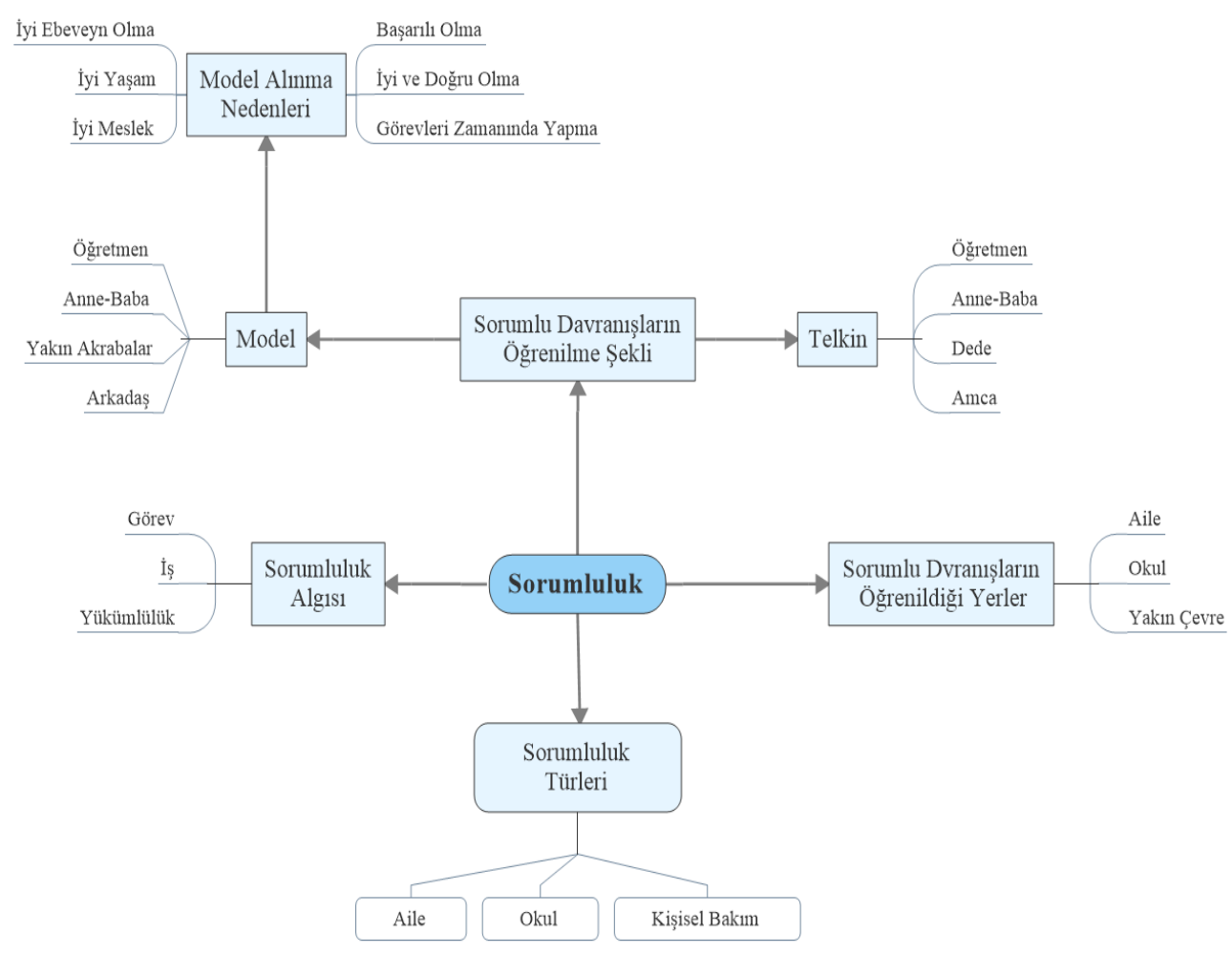

Şekil 1. İlkokul öğrencilerinin sorumluluk algısı, sorumlulukların ilgili oldukları alan, sorumlulukların öğrenildiği yerler ve öğrenilme şekli.

\section{Sorumluluk Algısı Teması ve Alt Kategorileri}

Şekil 1'de görüldüğg̈ gibi ilkokul öğrencilerinin sorumluluğa ilişkin algılarının "yerine getirilmesi gereken görevler, yükümlülükler ve işler” olduğu görülebilmektedir. Ödev yapma, oda toplama, anneye yardım, meslek sahiplerinin mesleki görevlerini yerine getirmesi, insanların yapması gereken şeyler, düzenli olmak, okul çantasını düzenleme, okula gitme, ders çalışma, test çözme, diş fırçalama, kitaplığı düzenli tutma gibi. Bunların bazılarının zorunlu olarak yapılması gerekirken, bazılarında böyle bir zorunluluk yoktur. Bu bakımdan bazıları görev, bazıları yükümlülük, bazıları da iştir. Öğrencilerin sorumluluk denilince aklına gelenleri çizdiği ve bazı açıklamalarda bulunduğu çalışmalardan bazıları aşağıda sunulmuştur: 


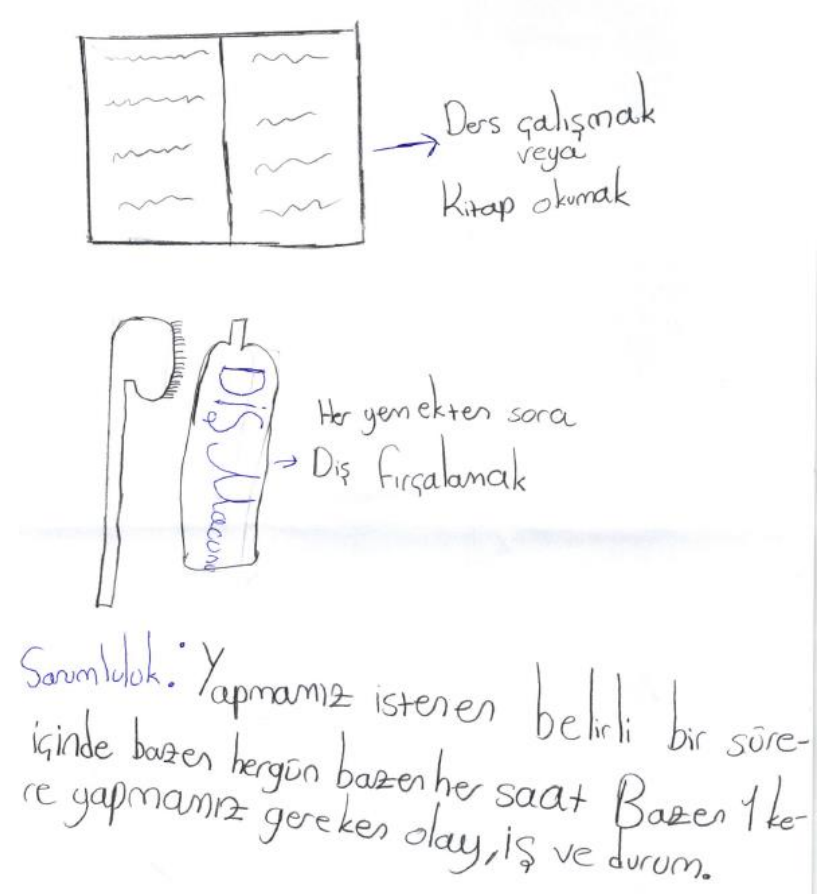

Resim 1.

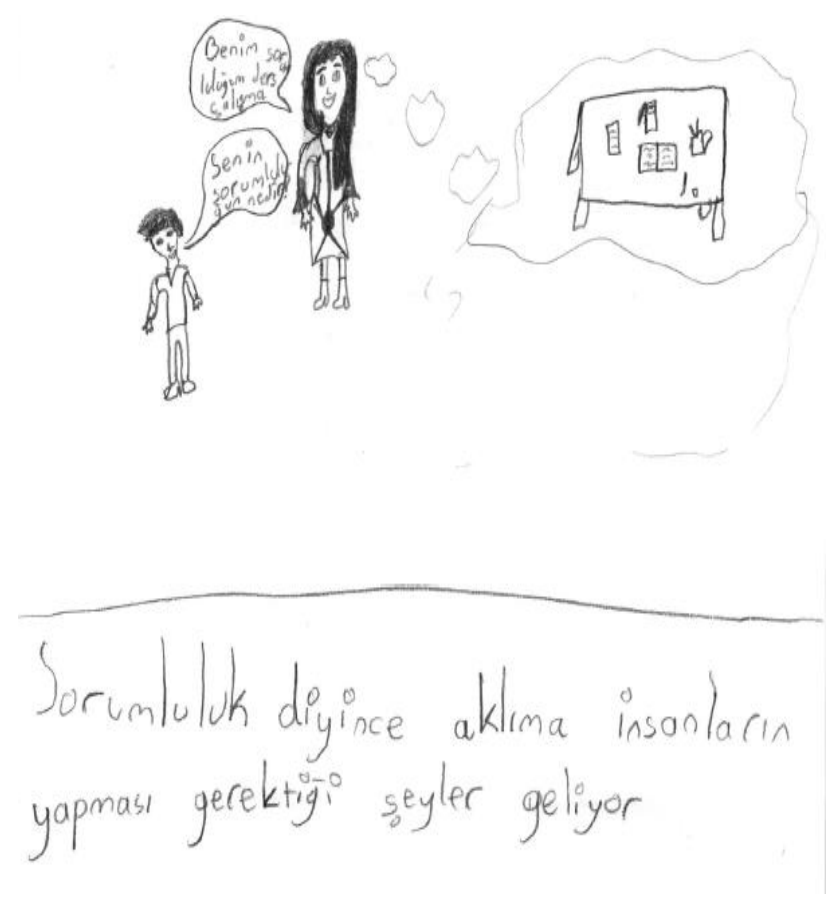

Resim 3.
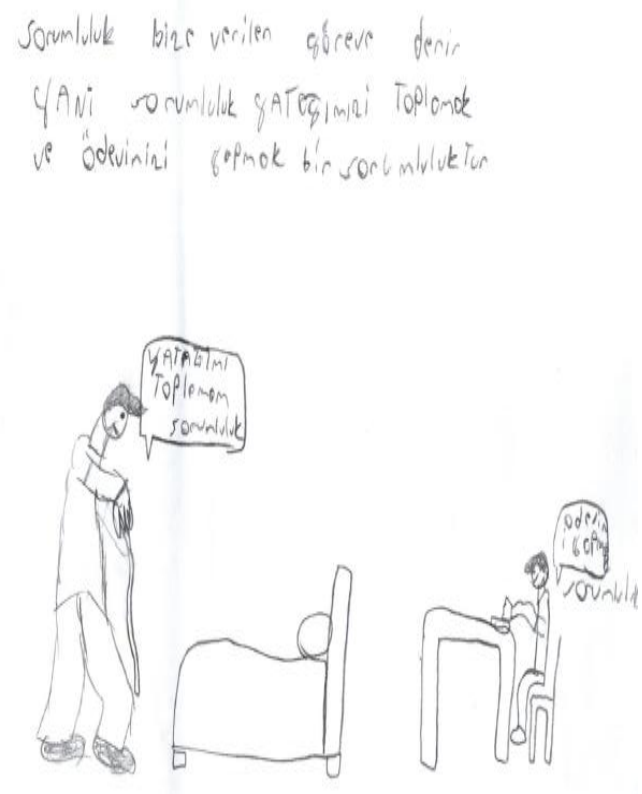

Resim 2.

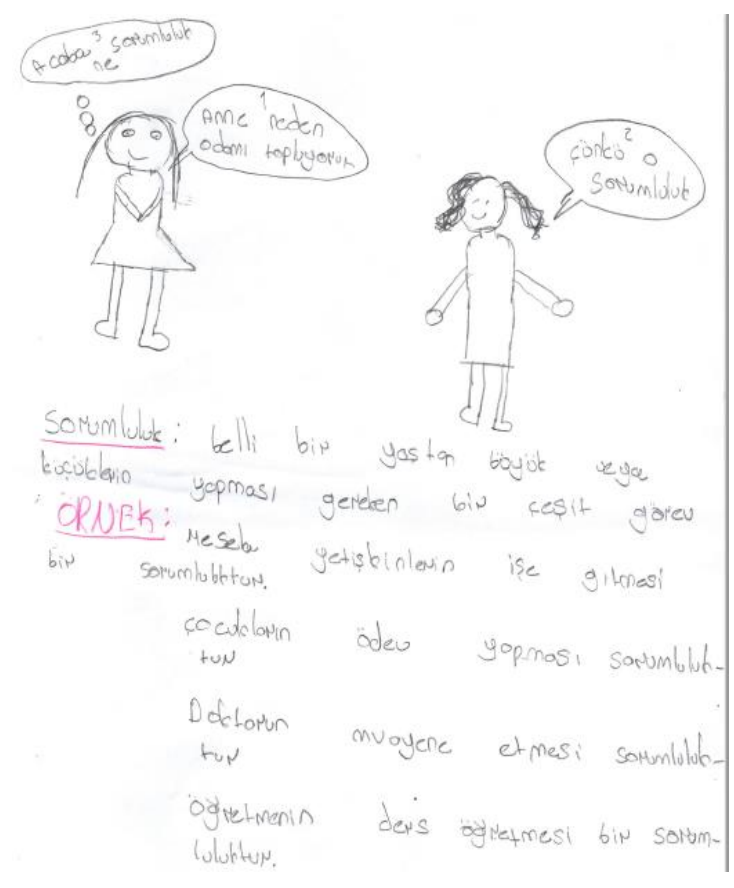

Resim 4.

Öğrenciler tarafından yapılan resimlerin ilkinde sorumluluk yapılması istenilen iş, durum ve olay olarak ele alınmıştır. Çizimde ise öğrenci bir kitap, diş macunu ve fırçasına ilişkin resim yapmıştır. Yaptığı çizimin yanında öğrenci ders çalışmayı, kitap okumayı ve diş firçalamayı sorumluluk davranışları olarak belirtmiştir. Bunun yanında öğrenci sorumluluğu "yapmamız istenen belirli bir süre içinde bazen her gün, bazen her saat bazen bir kere yapmamız gereken olay iş ve durum" olarak ifade etmiştir. Öğrencinin sorumluluğu ifade ederken yapmamız istenen ifadesini kullandığı görülmektedir. Bundan dolayı öğrencinin sorumluluk algısının motivasyon kaynağının dış 
kaynaklı olduğunu söyleyebilmek mümkündür. Yine öğrenci sorumluluğu iş ve görev olarak algıladığ1 görülebilmektedir. Bu iş ve görevler bazen her gün, bazen her saat, bazen de bir kere yapılarak icra edilebilmektedir. Aynı zamanda öğrencinin çizdiği resimde sorumluluklarının okul ve kişisel bakım alanlarında olduğu görülebilmektedir.

İkinci resimde öğrenci yatağını toplayan bir çocuk ile masada ders çalışan bir çocuk çizmiştir. Öğrenci sorumluluğu "Bize verilen göreve sorumluluk denir. Yani yatağımızı toplamak ve ödevimizi yapmak bir sorumluluktur" şeklinde ifade etmiştir. Öğrencinin sorumluluğu ifade ederken bize verilen göreve sorumluluk denir ifadesini kullandığı görülmektedir. Bu bakımdan öğrencinin de sorumluluk algısının daha çok dışsal motivasyon kaynakları tarafından şekillendiğini söyleyebilmek mümkündür. Yine öğrencinin sorumluğu kendisine yüklenen görev olarak algıladığı anlaşılmaktadır.

Üçüncü resimde öğrenci bir erkek ve kız arasındaki iletişim sürecinde sorumluğu ele almıştır. Buna göre ders çalışma bir sorumluluktur. Bunun öğrenci sorumluluğu “insanların yapması gerekenler şeyler" olarak ifade etmiştir. Bu bakımdan öğrencinin sorumluluk davranışlarını gereklilik veya yükümlülük olarak ele aldığını söyleyebilmek mümkündür.

Dördüncü resimde ise öğrencinin bir karikatür ile sorumluluğu ifade ettiği görülmektedir. Burada anne ile kızı arasındaki iletişim sürecindedir. Kız çocuğu sorumluluğun ne olduğunu merak etmektedir. Bunun yanında odasını neden topladığını annesine sormaktadır. Annesi ise oda toplamanın kendisinin sorumluluğun olduğunu ifade etmiştir. Ayrıca öğrenci resmin altında yapmış olduğu açıklamada “ belli bir yaşta küçük veya büyüklerin yapması gereken bir çeşit görev” olarak sorumluluğu belirtmiştir. Bunun yanında sorumluluğa ilişkin örnekler de vermiştir. Buna göre yetişkinlerin işe gitmeleri, çocukların ödev yapmaları, doktor ve öğretmenlerinin işleri ile ilgili bazı görevleri öğrenci tarafindan sorumluluk ile ilgili davranışlar olarak ele alınmıştır. Bu bağlamda öğrencinin yaşı ne olursa olsun her insanın sorumluluklarının olduğunu düşündüğünü söyleyebilmek mümkündür.

\section{Sorumluluk Türleri Teması ve Alt Kategorileri}

Şekil 1'de görüldüğü üzere ilkokul öğrencilerinin sorumluluk ile ilgili ifade ettikleri davranışların aileye karşı sorumluluklar, okul sorumlulukları ve kişisel bakım sorumluluklarıdır. Öğrenciler tarafından ifade edilen aileye karşı sorumlulukların odayı toplama, anneye ve kardeşlere yardım etme, düzenli olma; okuldaki sorumlulukların ders çalışma, dersi dinleme, ödevleri yapma, okul eşyalarına zarar vermeme, okul çantasının düzenleme; kişisel bakım ile ilgili sorumlulukların giysileri düzenli kullanma, duş alma, tırnak kesme, diş firçalama, el-yüz yıkama ve temiz olma olduğu görülmüştür. Bu duruma ilişkin öğrenci ifadeleri şunlardır:

$\ddot{U}$ : Evdeki sorumluluklarımı odamı toplama olabilir, anneme sofrayı kurarken yardım ediyorum. Okuldaki sorumluluklarımız okul eşyalarını korumak olabilir. Kişisel bakım sorumluluklarım tırnăğımı kesiyorum. 
B: Ders dinleme, ders çalışma, anneme yardım ediyorum, kardeşime baklyorum, oyuncaklarımı topluyorum, kalem falan dökülünce onları temizliyorum. Kişisel bakım ile ilgili tırnaklarımı kesiyorum, banyomu yapıyorum, dişlerimi firçalıyorum.

T: Ben ders çalışıyorum, dersi zamanında dinliyorum, kitap okuyorum, evde odamı topluyorum, kitaplı̆̆ düzenliyorum, giysilerimi dolabına yerleştiriyorum, tırnaklarımı kesiyorum, dişlerimi firçalıyorum.

\section{Sorumluluğun Öğrenildiği Alanlar Teması ve Alt Kategorileri}

Öğrencilerle yapılan görüşmede onların sorumluluk davranışlarını aile, okul ve yakın çevreden öğrendikleri görülmüştür. Bu durum Şekil 1'de de görülmektedir. Öğrenciler ailede daha çok anne, baba ve büyüklerden, okulda öğretmenlerinden ve diğer öğrenci arkadaşlarından, yakın çevreden ise dayı, amca, hala, teyze, dede, babaanne ve kuzenlerinden sorumluluk ile ilgili davranışları öğrendiklerini belirtmiştir Buna ilişkin öğrenci ifadeleri şunlardır.

H: Ailemden ögrrendim. Annem sorumlu olmam gerektiğini söylüyor. Gidip kuzenime göz kulak olmamı söylüyor. Bana sorumluluklarımı hatılatıyor. Abimden ödev yapmayı öğreniyorum.

Ü: Ailemden ögrrendim. Çünkü ailedeki her bireyin bana ögrettiği şeyler var. Mesela annem odamı toplamam gerektiğini, ders çalışmam gerektiğini söyleyebiliyor. Benim mesela kardeşime karşı sorumluluklarım var. Kardeşim bazen ders yaparken annem yorgun olduğunda ona ben derslerinde yardımcı oluyorum. Hani ailemdeki herkes bu gibi şeylerle bana sorumluluklarımı ögretti.

U: Öğretmenim, anne, baba, dede, amca, teyze, babaanne. Anne ve babam odamı toplamam gerektiğini söylüyor. Dişlerini firçala, çantanı hazırla diyor. Amcam ders çalış diyor. Dedem test çöz, kitap oku diyor.

E: Halalarımdan öğrendim. Ben uzun bir süre halalarımın yanında kaldım. Halalarım ders çalışmam gerektiğini evde neleri yapacağımı öğretti. Okulda öğretmenimden öğrendim. Nasıl ders çalışılacak neler yapılacak öyle.

\section{Sorumlu Davranışların Öğrenilme Şekli Teması ve Alt Kategorileri}

Örnek öğrenci ifadelerinden aynı zamanda yakın çevrelerinde bulunan (öğretmen, dede, anne, baba, amca) kişilerin telkin yoluyla sorumlulukları öğrencilere kazandırmaya çalıştıkları görülebilmektedir. Bunun yanında Şekil 1'de de görüldüğü üzere yapılan görüşmeden elde edilen bulgulara göre ilkokul öğrencileri sorumluluk ile ilgili davranışları model alma yoluyla da öğrenebilmektedir. Öğrencilere model olan kişilerin ailede anne, baba; yakın çevrede hala, kuzen, dayı; okulda ise öğretmen ve arkadaşlarıdır. Ayrıca bu kişilerin model olarak alınmalarının nedenleri görevlerini zamanında yerine getirmeleri, iyi ve doğru kişiler olmaları, başarılı olmaları, iyi bir mesleğe ve yaşama sahip olmaları ve iyi bir ebeveyn olmalarıdır. Bu duruma ilişkin örnek öğrenci ifadeleri aşağıda sunulmuştur: 
E: Halalarımı örnek alıyorum. Benim halalarım öğretmen ve ben de ögretmen olmayı istiyorum. Bir de halalarım planlı ve düzenli çalıştılar istediklerini alıyorlar ve istedikleri hayatı yaşıyorlar. Aynı zamanda başarılılar. Emeklerinin karşılıklarını aldıkları için ben de onları örnek alıyorum

T: Babam ve annem sorumluluklartn yerine getiriyorlar. Her sabah erkenden işe gidiyorlar. Ben de onları örnek allyorum. Ablam okula gidiyor ders çalışıyor. Kü̧̧ük kuzenime yardım ediyorlar. Ben de onlar gibi olacağım onları dikkate alıp izliyorum. Arkadaşım A... sırasını çok temiz tutuyor. Okuldan sonra sırasının altını temizliyor. Ondan okul eşyalarının düzenli kullanılmasını öğrendim. Benim doktor olan bir kuzenim var onun yanına da sik sık gidiyorum onun gibi olmak istiyorum

R:Babam her gün işe gidip geliyor. Para kazaniyor. Bende büyüyünce böyle bir sorumluluğum olacak. Her gün işe gidip geleceğim. Annem her gün ev işlerini yapıyor ve kardeşime yardım ediyor. Sorumluluklarını yerine getirmeleri benim için örnek oluyor. Doğru davranışları olan başarıll, sorumluluklarını bilen iyi insanları örnek alıyorum onlar gibi başarılı olacă̆ımı düşünüyorum

D: Kuzenim, anne ve babam. Çünkü kuzenim Türkiye 1. si onun gibi ders çalışıp başarılı olmak istiyorum. Anne ve babam işlerini zamanında yapıyor. Bende işlerimi zamanında yapmayı onlardan ögrendim.

$\ddot{U}:$ Öğretmenim sorumluluklarını yerine getiriyor. Derse zamanında gelip bizlere ders anlatıyor. Belirli bir saat aralı̆̆ında okulda kalması gerekiyor ve o bunu yapıyor. Benim ögretmenim sorumlulukların yerine getiriyor ve ben de bunu örnek allyorum. Ben de zamanı verimli kullanmaya çalışıyorum.

Örnek ifadelerde de görüldüğü üzere öğrenciler yakın çevresinde bulunan insanların sorumlulukla ilgili davranışlarını model almaktadır. Bu kişilerin iyi davranışları, zamanı planlı kullanımları, başarıları ve bunun sonucu iyi meslek ve yaşama sahip olmaları öğrencilerin onları örnek almalarını sağlamıştır.

\section{SONUÇ VE TARTIŞMA}

Araştırmada elde edilen bulgulara göre öğrencilerin sorumluluk algılarının görev, iş ve yükümlülük olduğu tespit edilmiştir. Karakuş, Kartal ve Çağlayan (2016) yapmış oldukları araştırmada ilkokul 4. sınıf öğrencilerinin sorumluluk değerini verilen görevi yerine getirme, zamanında yapılan iş, aldığı görevin arkasında durma olarak anlamlandırdıklarını saptamıştır. Aladağ (2009) da çalışmasında 5. sınıf öğrencilerinin sorumluluğu verilen görevlerin tam ve eksiksiz olarak yapılması şeklinde yorumladığını tespit etmiştir. Bunun yanında Çoban (2016) 6. sınıf öğrencilerinin kendilerine başkaları tarafından verilen görev olarak sorumluluğu belirttiklerini görmüştür. Araştırmada elde edilen bulgularla farklı araştırmalardan elde edilen sonuçlar ilkokul 4. sınıf öğrencileri ile ortaokul 5 ve 6 . sınıf öğrencilerinin sorumluluk algılarının oldukça benzer olduğunu ortaya koymaktadır. Bu durum gerek bilişsel gerekse de duyuşsal gelişim dönemi olarak öğrencilerin birbirine yakın dönemde yer almasında kaynaklanabilir. 
Araştırmada elde edilen bir başka bulgu öğrenciler tarafindan ifade edilen sorumluluk davranışlarının türlerinin aileye karşı sorumluluklar, okul sorumlulukları ve kişisel bakım sorumlulukları olduğudur. Sezer ve Çoban'ın (2016) çalışmasında ortaokul öğrencileri tarafından yedi farklı sorumluluk türü ifade edilmiştir. Bunlar "aileye karşı sorumluluk, "kişisel sorumluluk (akademik)", "kişisel sorumluluk (sağlık)", "kişiler arası sorumluluk”, "çevreye karşı sorumluluk", “dini sorumluluk" ve "kamusal sorumluluktur". Araştırma sonuçlarına göre ortaokul öğrencilerinin sorumluluğa ilişkin belirttikleri davranışlar ve bu davranışların türleri ilkokul öğrencilerine göre daha fazla ve farklıdır. Örneğin vergi verme, askere gitme gibi kamusal sorumluluklar ve çevreye karş1 sorumluluklar ortaokul öğrencileri tarafından ifade edilmiştir. Ancak ilkokul kademesinde bu tür sorumluluklar öğrenciler tarafından ifade edilmemiş̦tir. $\mathrm{Bu}$ durumun nedeni ortaokul düzeyinde okutulan Sosyal Bilgiler ve İnsan Hakları Yurttaşlık ve Demokrasi derslerinin içerik yönünden ilkokul Sosyal Bilgiler dersinden daha zengin olması olabilir.

Araştırma bulgularına göre evde odayı toplama ve temiz tutma, kitaplığı düzenleme, anneye yardım, kıyafetleri ve eşyalarını düzenli bir şekilde kullanma öğrenciler tarafından ifade edilen sorumlu davranışlardır. Yontar (2013) araştırmasında öğrencilerin ev ile ilgili sorumluluklarının düzen, yardımseverlik ve temizlik olduğunu tespit edilmiştir. Buna benzer şekilde Such ve Wolker (2004) çocukların evdeki sorumlulukları günlük yaşamın bir parçası olarak anlamlandırdığını belirlemiştir. Dal ve Selanik Ay (2014) ise çalışmasında evdeki sorumlulukların odayı düzenli tutuma, kardeş ile ilgilenme ve anne ve babaya yardım etme çocuklar tarafından ifade edilen evdeki sorumluluklardır. Bu bakımdan araştırma sonuçlarının uyumlu olduğunu söyleyebilmek mümkündür.

Araştırmada elde edilen sonuçlara göre öğrencilerin okul sorumluluklarının ders çalışma, dersi zamanında dinleme, kitap okuma, test çözme, ödev yapma, okul eşyalarına zarar vermeme, okul çantasını hazırlamadır. Aktepe (2015) tarafından yapılan çalışmada ilköğretim beşinci sınıf öğrencilerinin okuldaki sorumluluklarını yerine getirdikleri ve dersi zamanında dinlediklerini tespit edilmiştir. Bu bağlamda ilkokul 4. sınıf ile ilköğretim 5. sınıf düzeylerinin birbirine çok yakın dönemler olması nedeniyle öğrencilerin okul ile ilgili sorumlu davranışları benzer şekilde anlamlandırdığ ifade edilebilir.

Araştırma bulguları ilkokul 4. sınıf öğrencilerinin diş fırçalama, banyo yapma ve tırnak kesme gibi kişisel bakım sorumluluklarını ifade ettiklerini ortaya koymaktadır. Gömleksiz ve Cüro'nun (2011) araştırmasında sorumluluk ile ilgili olarak 7. sınıf öğrencilerinin en fazla "kişisel temizliğime önem veririm” biçiminde görüş ifade ettiği saptanmıştır. İlkokul ve ortaokul öğrencilerinin kişisel bakım ile ilgili bazı davranışları sorumluluk olarak anlamlandırabildiğini söyleyebilmek mümkündür.

Öğrencilerin günlük hayatta sorumluluğu öğrendiği yerler aile, okul ve yakın çevredir. Çeşitli araştırmalarda da benzer bulgular saptanmıştır. Örneğin Ünlü (2019) ile Çelikkaya ve Seyhan (2016) araştırmalarında öğrencilerin değer tercihlerinin yakın çevresinden (anne, baba, öğretmen, arkadaş vb.) 
etkilendiği görülmektedir. Meydan ve Bahçe'nin (2010) çalışmasında sınıf öğretmenleri, öğrencilerin değer gelişiminde çevrenin önemine dikkat çekmiştir. Ünlüer (2012) tarafından yapılan çalışmada öğrenci velilerinin sorumluluk değerinin çocuklarda kazanmasında çevrenin önemli olduğu ifade ettiği görülmektedir. Benzer şekilde aile ve okulun çocukların sorumluluk değerini kazanmalarında etkisi çeşitli araştırmalarda tespit edilmiştir. Örneğin Yontar (2007) çocuklarda sorumluluk değerinin gelişmesinde anne- baba tutumunun ve disiplin anlayışının etkili olduğunu saptamıştır. Çınar, Teyfur ve Teyfur (2006) ailede başlayan sorumluluk eğitiminin okulda devam ederek pekiştirildiğini belirtmektedir. Lan- ying'e (2010) göre ise okulların bir görevi de öğrencilere sorumluluk değerini kazandırmadır. Araştırmada elde edilen bulgular ile diğer çalışmaların sonuçları ilkokul öğrencilerinin sosyal yaşamda daha fazla vakit geçirdiği alan ve ortamlar olan aile ve okulda etkileşim içinde olduğu insanlardan sorumluluk değerini çeşitli şekillerde öğrendiğini ortaya koymaktadır.

Araştırma sonuçlarına göre öğrenciler sorumlu davranışları model alma ve telkin yoluyla öğrenmektedir. Öğrencilerin ailesinde, yakın çevresinde bulunan bazı kişilerle ve öğretmenin öğrencilerin sorumluluk değerini kazandırmada telkin yaklaşımını kullandığı görülmüştür. Bunun yanında öğrencilerin yakın çevresinde bulunan akrabalarını ve öğretmelerini model aldığı saptanmıştır. $\mathrm{Bu}$ bağlamda model olmanın telkin yöntemine göre daha etkili olabileceği söylenebilir. Ayrıca araştırmada öğrencilere model olan kişilerin hayatlarında başarılı olmaları, iyi yaşam ve mesleğe sahip olmaları, iyi bir insan, anne baba olmaları ve görevlerini zamanında yerine getirmeleri onların öğrenciler tarafından örnek almalarını sağlamıştır. Sosyal öğrenme kuramında (Bandura, 1989) bireylerin beğendiği ve saygı duyduğu kişileri model alarak duyuşsal davranışlar kazandığı belirtilmektedir. Rol model olan kişiler ise sahip oldukları nitelikler, beceriler, başarılar ve özellikler yönleriyle başkaları tarafından örnek alınan kişilerdir (Ricer, 1998; Karaoğlu, 2012). Bu bağlamda ilkokul öğrencilerinin yakın çevrelerinde bulunan başarılı kişileri sorumlu davranışları yönünden örnek aldığı söylenebilmektedir. Bunun yanında Kabaklı Çimen (2019) tarafından yapılan araştırmada öğretmen adaylarının anne babalarını, aile yakınlarını, öğretmenlerini, başarılı kişileri ve siyasi liderleri rol model aldıkları belirlenmiştir. Bu bağlamda araştırma bulgularının büyük ölçüde tutarlılık gösterdiğini söyleyebilmek mümkündür.

Araştırma bulgularına göre öğrenciler model alma ve telkin yöntemiyle değer öğrendiklerini ifade etmektedir. Bu bakımdan ebeveynlerin, öğretmenlerin ve yakın çevrede bulunan insanların yaparak yaşayarak sorumluluk değerini öğrenmeye dönük görev temelli etkinlikleri kullanmadıklarını söyleyebilmek mümkündür. Ancak özellikle küçük yaşlarda sorumluluk değerinin öğrencilere kazandırılmasında yaşantı temelli etkinliklerin nasihat odaklı anlatımlardan daha etkili olduğu çeşitli araştırmalarda (Brecke ve Jensen, 2007; Clouder, 2009; Macready, 2009; Ramos \& TolentinoAnınuevo, 2011; Sierra, 2009; Stockdale \& Brockett, 2010; Töremen, 2011) saptanmıştır. Bu bakımdan telkin yaklaşımından ziyade öğretmenlerin ve ailenin yaşantı temelli etkinliklerle öğrencilere sorumlu davranışları kazandırması önerilebilir. 
Araştırma sonuçlarına göre öğrencilerin sorumluluğu ifade ederken çevreye karşı sorumluluklardan hiç bahsetmedikleri görülmektedir. Bu bağlamda Sosyal Bilgiler, Fen Bilimleri ve Hayat Bilgisi ders kitaplarının içerikleri çevreye karşı sorumluluklar konusunda zenginleştirilebilir. Araştırmacılar Hayat Bilgisi, Sosyal Bilgiler ve Fen Bilimleri derslerinin sorumluluk değerini kazandırmayı amaçlayan konularını öğretmede araştırma bulgularına göre öğrenme yaşantıları oluşturup bu çalışmaların etkililiğine dair eylem araştırmaları ve deneysel çalışmalar gerçekleştirebilir.

\section{KAYNAKÇA}

Ackerman, S., Hughs, L., \& Wilder, R. (1997). Improving student responsibility. Illinois: Masterís Action Research Project, Saint Xavier University \& IRI/Skylight. (ERIC Document Reproduction Service No. ED411957).

Acun, İ., Yücel, C., Önder, A. \& Tarman, B. (2013). Değerler: Kim ne kadar değer veriyor?, Uşak Üniversitesi Sosyal Bilimler Dergisi, 6 (1), 191-206.

Aktepe, V. (2015). 5. Sınıf Öğrencilerinin Sorumluluk Değerinin Geliştirilmesine Yönelik Bir Performans Görevi Uygulaması. Kastamonu Eğitim Dergisi, 23(4), 1511-1534.

Aladağ, S. (2009). İlköğretim sosyal bilgiler öğretiminde değer ĕgitimi yaklaşımlarının ögrencilerin sorumluluk değerini kazanma düzeyine etkisi. (Yayımlanmamış doktora tezi), Gazi Üniversitesi Eğitim Bilimleri Enstitüsü, Ankara.

Altun, S. D. (1999). İşletmelerde sosyal başart stratejileri ve İstanbul boya işletmelerinin sosyal sorumluluk seviyeleri üzerine bir araştırma. (Yayınlanmamış Yüksek Lisans Tezi), Marmara Üniversitesi Sosyal Bilimler Enstitüsü, İstanbul.

Baydar, P. (2009). İlköğretim beşinci slnıf sosyal bilgiler programında belirlenen değerlerin kazanım düzeyleri ve bu süreçte yaşanan sorunların değerlendirilmesi. (Yayınlanmamış Yüksek Lisans Tezi), Çukurova Üniversitesi Sosyal Bilimler Enstitüsü, Adana.

Bandura, A. (1989). Human agency in social cognitive theory. American Sychologist-American Psychological Association, 44 (9), 1175-1179.

Başaran, İ. E. (1974). Eğitim psikolojisi (3. Baskı).Ankara: Yargıçoğlu.

Brecke, R. \& Jensen, J. (2007). Cooperative learning, responsibility, ambiguity, controversy and support in motivating students. InSight: A Collection of Faculty Scholarship, 2, 57-63.

Can, Ö. (2008). Dördüncü ve beşinci sınıf öğretmenlerinin sosyal bilgiler dersinde değerler eğitimi uygulamalarına ilişkin görüşleri.(Yayımlanmamış Yüksek Lisans Tezi), Hacettepe Üniversitesi Sosyal Bilimler Enstitüsü, Ankara.

Clouder, L. (2009).'Being responsible': students' perspectives on trust, risk and work-based learning. Teaching in Higher Education, 14(3), 289-301.

Civelek, B. (2006). Çocuklara sorumluluk bilinci kazandırmak. Çoluk Çocuk Aylık Anne Baba Eğitimci Dergisi, 58, 20-22.

Creswell, J. W. (2009). Research design qualitative, quantitative, and mixed methods approaches. Sage Publication, Thousand Oaks: California.

Cüceloğlu, D. (1996) İçimizdeki çocuk. İstanbul: Remzi Kitabevi. 
Çelikkaya, T., Filoğlu, S. \& Öktem, N. (2013). Sosyal bilgiler dersinde değerler eğitimi Uygulamalarının öğretmenler tarafindan uygulanma düzeyleri. Sosyal Bilgiler Eğitimi Araştırmaları Dergisi, 4(1), 121-147.

Çelikkaya, T., \& Seyhan, O. (2016). Değerlerin kazanılmasındaki etkili faktörler (öğrenci görüşleri). Ballkesir Üniversitesi Sosyal Bilimler Enstitüsü Dergisi, 19(36), 167-191.

Çınar, O., Teyfur, E. \& Teyfur, M. (2006). İlköğretim okulu öğretmen ve yöneticilerinin yapılandırmac1 eğitim yaklaşımı ve programı hakkındaki görüşleri. Inönü Üniversitesi Eğitim Fakültesi Dergisi, 7 (11), 47-64.

Çoban, O. (2016). Sokratik sorgulama yöntemi ile sorumluluk değerinin öğretimi. (Yayınlanmamış Doktora Tezi), Uşak Üniversitesi Sosyal Bilimler Enstitüsü, Uşak.

DiCicco-Bloom, B., \& Crabtree, B. F. (2006). The qualitative research interview. Medical Education, 40, 314-321.

Glesne, C. (2012). Nitel araştırmaya giriş (1. Baskı) A. Ersoy ve P. Yalçınoğlu (Çev. Edt.). Ankara: Anı.

Gömleksiz, M. N. \& Cüro, E. (2011). Sosyal Bilgiler dersi öğretim programında yer alan değerlere ilişkin öğrenci tutumlarının değerlendirilmesi, Uluslararası İnsan Bilimleri Dergisi, 8 (1), 95-134

Greig, A. D., Taylor, J., \& MacKay, T. (2007). Doing research with children. 2nd edition. London: Sage Publications.

Gunnestad, A., Mørreaunet, S., Granseth, I. \& Vikan, A. (2013). Barns oppfatning av tilgivelse [Children's understanding of forgiveness]. Norsk Pedagogisk Tidsskrift. Forum for pedagogikk og fagdidaktikk içinde (s. 408-417).

Kabaklı Çimen, L. (2019). Eğitim fakültesi öğrencilerinin rol model tercihleri. Manas Sosyal Araştırmalar Dergisi, 8(1), 88-11

Karakuş, C., Kartal, A., \& Çağlayan, K. T. (2016). İlkokul öğrencilerine göre sorumluluk. Ankara Üniversitesi Eğitim Bilimleri Fakültesi Dergisi, 49(1), 1-20.

Karaoğlu, N. (2012). Tip eğitiminde rol modellik ve aile hekimliği için önemi. Turkısh Journal Of Famıly Medicıne and Primary Care (Tjfmpc), 6(2): 30-35

Lan-ying, Z. (2010). Base on the realities to foster a strong sense of responsibility and achieve the sustainable development of vocational schools. Canadian Social Science, 6 (5), 157-163.

Liamputtong, P. (2009). Qualitative data analysis: Conceptual and practical considerations. Health Promotion Journal of Australia, 20(2), 133-139.

Lickona, T. (1991). Educating for character: How our schools can respect and responsibility. New York: Bantam Books.

Lee, N., \& Kotler, P. (2006). Kurumsal sosyal sorumluluk (Çev. S. Kaçamak). İstanbul: Mediacat.

Leitch, R. (2008). Creatively researching children's narratives through images and drawings. In: Thomson, P. (ed.) Doing Visual Research with Children and Young People (s. 37- 57). London and NewYork: Routledge.

Macready, T. (2009). Learning social responsibility in schools: a restorative practice. Educational Psychology in Practice, 25(3), 211-220.

Malchiodi, C. A. (2005). Çocukların resimlerini anlamak. Yurtbay, T. (Çev.) İstanbul: Epsilon Yayıncılık. 
Meydan, A. \& Bahçe, A. (2010). Hayat bilgisi öğretiminde değerlerin kazandırılma düzeylerinin öğretmen görüşlerine göre değerlendirilmesi. Uluslararası Avrasya Sosyal Bilimler Dergisi, 1(1), 20-37.

Miles, M.B. \& Huberman, A.M. (1994) Qualitative data analysis: an expanded sourcebook (2nd. Ed). London: Sage.

Moritz, S., Wahl, K., Zurowski, B., Jelinek, L., Hand, I., \& Fricke, S. (2007). Enhanced perceived responsibility decreases metamemory but not memory accuracy in obsessive-compulsive disorder (OCD). Behaviour Research And Therapy, 45(9), 2044-2052.

Mowling, C. M., Brock, S. J. \& Hastie, P. A. (2011). African-American Children's Representation of Personal and Social Responsibility, Sport, Education and Society, 16 (1), 89-109.

Nelson, D. B., \& Low, G. R. (2004). Personal responsibility map. Oakwood Solutions, Lic.

Patton, M., C. (2002). Qualitative method and evaluation methods. Sage Publication, Thousand Oaks: California.

Popkin, M. (1987). Active parenting: Teaching, cooperation and responsibility. San Fransisco: Harper \& Row Publishers.

Ramos, R.C. \& Tolentino-Anonuevo, M.J. (2011). Engagement-promoting aspects of teacher's instructional style and academic self regulated learning. The International Journal of Research and Review, 7(2), 51-61.

Ricer, R.E. (1998). Defining preceptor, mentor, and role model. Family Medicine, 30(5), 328.

Selanik Ay, T., \& Dal, S. (2014). İlköğretim öğrencilerinin yazılı anlatım ürünlerine göre sorumluluk değeri algıları. Dicle Üniversitesi Ziya Gökalp Eğitim Fakültesi Dergisi, 22, 78-93.

Seyyar, A. (2003). Ahlak terimleri (Ansiklopedik sözlüğ̈̈). İstanbul: Beta.

Sezer, A., \& Çoban, O. (2016). Ortaokul öğrencilerinin sorumluluk değeri algıları. Uşak Üniversitesi Eğitim Araştırmaları Dergisi, 2(1), 22-39.

Sierra, J.J. (2009). Shared responsibility and student learning: Ensuring a favorable educational experience. Journal of Marketing Education, 32 (1) 104-111

Stockdale, S.L. \& Brockett, R.G. (2010). Development of the PROSDLS: A measure of self-direction in learning based on the personal responsibility orientation model. Adult Education Quarterly, 200(10), $1-20$.

Such, E. \& Walker, R. (2004). Being responsible and responsible beings: children's understanding of responsibility. Children \& Society, 18, 231-242.

Şahan, E. (2011). İlköğretim 5. ve 8. sinıf ders programlarındaki sorumluluk eğitimine dönük kazanımların gerçekleşme düzeyleri. (Yayınlanmamış Yüksek Lisans Tezi), Ahi Evran Üniversitesi Sosyal Bilimler Enstitüsü, Kırşehir.

Tay, B., Durmaz, F. \& Şanal, M. (2013). Sosyal Bilgiler dersi kapsamında öğrencilerin değer ve değerler eğitimine ilişkin görüşleri, Gazi Eğitim Fakültesi Dergisi, 33 (1), 67-93.

Töremen, F. (2011).The responsibility education of teacher candidates. Educational Sciences: Theory \& Practice, 11(1), 273-277.

Ünlü, İ. (2019). İlkokul öğrencilerinin değer yönelimlerinin ahlaki ikilem hikâyeleriyle incelenmesi: sorumluluk değeri örneği. Journal of Graduate School of Social Sciences, 23(1). 
Ünlüer, G. (2012). Sosyal Bilgiler dersinde sorumluluk değerinin kazandırılmasına ilişkin veli görüşleri. Eğitim ve İnsani Bilimler Dergisi: Teori ve Uygulama, (6), 95-116.

Yavuzer, H. (2000) Çocuk eğitimi el kitabı. İstanbul: Remzi Kitabevi.

Yeşil, R. (2003). Sorumluluk bilincinin gelişmesine okul ve ailenin Etkisi. Eğitim Araştırmaları Dergisi, 9, $175-183$.

Yeşil, R. (2013). Ortaöğretim öğrencilerinin okul öğrenmelerindeki öğrenme sorumluluklarını yerine getirme düzeyleri. Uluslararası İnsan Bilimleri Dergisi, 10(1), 1214-1237.

Yeşil, R. (2014). İlköğretim okullarında görev yapan öğretmenlerin sorumluluk eğitimi stratejilerinin incelenmesi. Hacettepe Üniversitesi Ë̆itim Fakültesi Dergisi, 29 (2), 282-294.

Yeşilyaprak, B. (2002). Eğitimde rehberlik hizmetleri (3.Baskı). Ankara: Nobel Yayınları.

Yıldırım, A. \& Şimşek, H. (2005). Sosyal bilimlerde nitel araştırma yöntemleri. (Beşinci Basım). Ankara: Seçkin Yayıncıllk.

Yiğittir, S. (2010). İlköğretim öğrenci velilerinin okullarda kazandırılmasını arzuladığı değerler. Değerler Eğitimi Dergisi, 8 (19), 207-223.

Yontar, A. (2013). Sorumluluk ile empati iliş̧kisinin İncelenmesi. (Yayınlanmamış Doktora Tezi), Gazi Üniversitesi Eğitim Bilimleri Enstitüsü, Ankara.

Yontar, A. (2007). Sorumluluk eğitiminde ceza uygulamalarına iliş̧kin ilköğretim 5.sınıf öğrenci ve ögretmen görüşlerinin incelenmesi, (Yayımlanmamış Yüksek Lisans Tezi). Çukurova Üniversitesi Sosyal Bilimler Enstitüsü, Adana.

Yontar, A. \& Yurtal, F. (2009). Sorumluluk kazandırmada öğretmenler tarafından kullanılan yaptırımların incelenmesi. Eğitim ve Bilim, 34(153), 144-156. 


\section{EXTENDED SUMMARY}

So as to adapt to the society where an individual lives, he / she has to acquire some values. The two most crucial fields to add value to individuals are doubtlessly family and school. Parents and close relatives in the family environment and teachers at school have crucial roles in gaining children's values. Many studies revealing the role of family and school in acquiring values of students have been encountered in educational research conducted in recent years. Besides, in the curriculum developed in 2005 with a constructivist approach, goals, achievements, methods and learning contents have been struggled to be established so as to gain various values to the students. Some national and universal values are aimed to be gained to students in primary school level such as life science, social studies, science and Turkish. One of these values is responsibility.

Responsibility is not an value which comes from birth. It is essential to have a number of experiences for people to acquire responsible behaviors. Ackerman, Hughs and Wilder (1997) draw attention to this situation. According to this,it is not enough to talk to the students for gaining responsibility. Instead of this, they should be provided opportunities to learn responsibility. In respect to this, it is significant to give students responsibility by means of education and real-life experiences (Gunnestad, Mørreaunet, Granseth \& Vikan, 2013; Yeşil, 2013; Yontar \& Yurtal, 2009). The need to gain responsibility by means of education has increased during the recent years. Because Yeşil (2014) states that the source of social, economic, political, military and ecological problems which are experienced in nearly every part of the world is basically because of the fact that individuals do not act responsibly. On behalf of the solution of these problems, it can be said that education may have an significant function for gaining responsibility value to individuals.

According to Yeşilyaprak (2002), primary school period is a crucial period for students to acquire various competence and skills related to responsibility. It is said that determination how the students in this period perceive and learn responsibility will also have a guiding effect to training for the next period. Furthermore, it is thought that the results which are obtained in the research will provide significant point of view to the experts and teachers who develop programs as to responsibility education. The purpose of this study is to investigate sense of responsibility, behaviors and learning experiences of students from primary school. In respect to this, the following questions are sought in the research:

How does primary school students make sense of responsibility?

What are the experiences of primary school students in learning responsibility behaviors? 


\section{Method}

\section{Pattern of Research}

This research was conducted by using phenomenology that is one of the qualitative research patterns. In the phenomenology pattern, the experiences of the individuals related to a phenomenon and the meanings attributed to it are struggled to be revealed.

\section{Workıng Group}

In the research,typical case sampling that is one of the purposeful sample types was used in the selection of working group. In the study,the purpose is to investigate the perception of responsibility of students at lower and middle socio-economic levels. With the effect of this purpose, the research was conducted in a primary school with lower and middle socio-economic students. In this school, 10 students from fourth grade participated in the study.

\section{Data Collection Tools}

In the research, the data were collected with pictures and semi-structured interviews that were conducted by students.

\section{Data Analysis}

Data obtained from pictorial expressions of children and written expressions based upon pictorial expression were investigated by means of document analysis. In the analysis of semistructured interviews, it was made use of the thematic analysis. Liamputtong (2009) states that the thematic analysis is aimed at conceptualizing data and revealing themes.

\section{Conclusions, Discussion and Suggestions}

It can be seen that perceptions of students from primary school as to responsibility are tasks, obligations and jobs that need to be fulfilled.These are like doing homework, collecting rooms, helping the mother, fulfilling the professional duties of the professionals, things that people need to do, being organized, organizing the school bag, going to school, studying lesson, solving the test, brushing teeth, keeping the library tidy. Even though some of them must be made necessarily, there is no obligation for others. In respect to this, some of them are duties and some of them are obligations. Also others are jobs.

Another finding obtained in the research is that the types of responsibility behaviors expressed by the students are responsibilities for family, school responsibilities and personal care responsibilities.

Places where students learn responsibility in everyday life are family, school and immediate vicinity. Similar findings have been found in various studies. 
In accordance with the results of the research, students learn responsible behaviors by means of modeling and suggestion. İt was found out that parents, people in the vicinity and teachers Besides, it was found out that the students took their relatives and teachers as models. In this context, it can be said that being a model could be more effective than inculcation. Also, the model for students in the research being successful in their lives,having a good life and job,being a good person,being a good parent and fulfilling their duties in a timely manner provided to be the model for students. In social learning theory (Bandura, 1989), it is stated that individuals gain affective behaviors with the help of taking role models the people they like and respect. People who are role models are people who are taken as role models by others with regard to their qualifications, skills, achievements and features (Ricer, 1998; Karaoğlu, 2012). In this context, it can be said that elementary school students take the successful people in their immediate vicinity as examples in terms of responsible behaviors.

According to the results of the research, it is seen that the students never mentioned the responsibilities towards the environment when they express responsibility. In this context, the contents of Social Studies, Science and Life Science textbooks could be enriched with regard to environmental responsibilities. Researchers may create life experiences based on the research findings and perform action research and experimental studies related to the effectiveness of these studies in teaching the subjects that aim to gain the responsibility value of Social Sciences,Social Studies and Life Science courses. 